Utah State University

DigitalCommons@USU

\title{
Phytoalexin production by aspen (Populus tremuloides Michx.) in response to infection by Hypoxylon mammatum (Wahl.) Mill. and Alternaria spp
}
G. Flores
M. Hubbes

Follow this and additional works at: https://digitalcommons.usu.edu/aspen_bib

Part of the Forest Sciences Commons

\section{Recommended Citation}

Flores, G. and Hubbes, M., "Phytoalexin production by aspen (Populus tremuloides Michx.) in response to infection by Hypoxylon mammatum (Wahl.) Mill. and Alternaria spp" (1979). Aspen Bibliography. Paper 4685.

https://digitalcommons.usu.edu/aspen_bib/4685

This Article is brought to you for free and open access by the Aspen Research at DigitalCommons@USU. It has been accepted for inclusion in Aspen Bibliography by an authorized administrator of DigitalCommons@USU. For more information, please contact

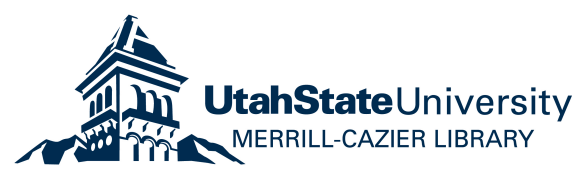


Faculty of Forestry and Landscape Architecture, University of Toronto

\title{
Phytoalexin production by Aspen (Populus tremuloides Michx.) in response to infection by Hypoxylon mammatum (Wahl.) Mill and Alternaria spp.
}

By G. Flokt:s and M. HubBles

Receipt of Ms. 10.8.1978

\begin{abstract}
Freshly wounded stem sections of $P$. tremuloides Michx. produce phytoalexin when inoculated with mycelium of Hypoxylon mammatum (Wahl.) Mill., and Alternaria sp. These exudates are inhibitory against spore germination of these two fungi and, although inhibitory against mycelial growth of Alemara sp., have no effect on the mycelial growth of $H$. mammatum. It was possible to correlate the amount of phytoalexin elicited by different strains with the inhibiory activity.
\end{abstract}

\section{Introduction}

In higher plants, attempts have been made to relate disease resistance to either the occurrence of structural or physical barrices, or to the presence of an inhibitory compound or compounds within the tissues of the host. The broad categories of structural and chemical defence mechanisms are often sublivided according to whether a particular mechanism is operative before infection (pre-infectional resistance) or develops as a direct consequence of the physiological interaction between the plant and the potential pathogen (postinfectional resistance), InGHAM (1973).

U.S. Copyright Clarance Center Code Statement: 0300-1237/79/0905/0280\$02.50/0

E.ur. J For. Path. 9 (1979) 280-288

(c) 1979 Verlag Paul Parey, Hamburs und Berlin

ISSN 0300-1237: ASIN Cocken: BJIPA9 
Until a few decades ago, little was known about the physiology of the host-parasite relationship of Hypoxylon canker caused by Hypoxylon mammatum (Wahl.) Mill. Subsequently, Huвbes $(1962,1962 \mathrm{a}, 1964)$ showed that aspen bark contained various compounds that were inhibitory to the growth of H. mammatum. These compounds could be classed as pre-infectional since they are found to be present in the host tissues and are operative before fungal attack.

The objective of this research was to investigate the role of post-infectional compounds as a direct result of the physiological interaction between the host and the pathogen.

\section{Materials and methods}

\subsection{Isolation of H. mammatum}

Diseased aspen (Populus tremuloides) material was collected from the Maple Woodlot, 25 miles north of Toron to, Ontario, Canada during the Fall of 1975. Small pieces of sapwood were cut and placed on 2 per cent malt agar. Isolations were made from various places above and below the cankers and the plates were incubated at $28^{\circ} \mathrm{C}$. Five isolates from the Maple Woodlot (MWL) vis: MWLI, MWL II, MWL III, MWLIV and MWL, V, were used. One isolate from Quebec (Q) was provided by the Laurentian Forest Research Centre, Quebec City,

\subsection{Production of exudates by Hypoxylon}

Aspen stems about $9-10$ years old were cut and stored at $-35^{\circ} \mathrm{C}$. The frozen material was cut into sections $33 \mathrm{~cm}$ in length and split into quarters. The thin layer (phellem) and the green layer (cortex part of the secondary phloem) immediately beneath the outer layer, were removed at different intervals to form small debarked discs, approximately $1.5 \mathrm{~cm}$ in diameter and placed over petri dishes kept submerged in water in a polypropylene sterilizing pan $31.2 \times 25.0 \times 13.3 \mathrm{~cm}$. The pan was covered with saran wrap to maintain high humidity. Agar plugs with actively growing $H$. mammatum were placed on the debarked discs and the pans were incubated at $28^{\circ} \mathrm{C}$. Exudates were collected by means of glass disposable Microsampling pipette and stored in the freezer at $-35^{\circ} \mathrm{C}$.

\subsection{Ascospore collection}

H. mammatum ascospores were collected by placing the perithecia in $60 \times 15 \mathrm{~mm}$ petri dish covers which in turn were kept in a $150 \times 20 \mathrm{~mm}$ petri dish with water. A drop of sterile distilled water was put on top of perothecia and incubated for 24 hours at $28^{\circ} \mathrm{C}$. The ascospores which were released on the petri dish cover were washed with sterile distilled water and kept in suspension.

\subsection{Hypoxylon ascospore germination test}

The spore suspension was diluted to 100000 spores/ $\mathrm{ml}$ by using a Bright-Line Hemacy tometer. By means of a disposable pipette two drops $(0.02 \mathrm{ml})$ were transferred to each of three wax rings made on a glass slide with the help of a cork-borer No. 8 . The glass slides were then placed over cotton rolls in a $150 \times 20 \mathrm{~mm}$ sterile petri dish containing glass beads and water These were incubated at $35^{\circ} \mathrm{C}$ until maximum germination of spores in the rings occurred. The germinated ascospores were then counted. 


\subsection{Isolation of Alternaria sp.}

Leaves from Populus deltoides Bartr. with Alternaria leafspots were collected at Maple, Ontario. Isolation of the fungus from diseased leaf tissues, was carried out on 2 per cent malt agar and the plates incubated at $25^{\circ} \mathrm{C}$.

\subsection{Spore germination test with Alternaria sp.}

Spore suspensions of Altemaria sp. were prepared by washing the spores in $20 \mathrm{ml}$ of distilled water from actively growing cultures on malt agar plates. The suspension containing the spores and mycelium was centrifuged at $3600 \mathrm{r} . \mathrm{p} . \mathrm{m}$. and filtered through cheese-cloth to remove the mycelium. The spore suspension was diluted so that each $\mathrm{ml}$ of suspension contained approximately 100.000 spores. Spore germination was tested in the same manner as described in section 2.4. However, the spores were incubated at $25^{\circ} \mathrm{C}$ for 5 hours.

\subsection{Action of exudates against Hypoxylon ascospore germination}

Ascospore germinations were tested in the same manner as described in section 2.4, except in the treatments 20 microlitres of crude exudate were incorporated to the spore suspension $(0.02 \mathrm{ml})$ with the help of $g$ lass disposable Micro-sampling pipette. The controls were treated with equal amounts of sterile distilled water.

\subsection{Action of exudates against Alternaria spore germination}

Procedures followed for this part of the study were the same as described in sections 2.6 and 2.7 .

\subsection{Action of exudates against Alternaria mycelial growth}

$20 \mathrm{ml}$ of the spore suspension, adjusted to 100000 spores $/ \mathrm{ml}$, was mixed thoroughly with $250 \mathrm{ml}$ of 2 per cent malt agar just before it started to solidify. The agar was poured into $100 \times 25 \mathrm{~mm}$ glass petri dishes and allowed to solidify. Sterile filter paper dises were then soaked in respective exudates and placed on the seeded agar plates. Sterile filter paper discs soaked in sterile distilled water were used as controls and placed in the center of the plates. The plates were incubated at $25^{\circ} \mathrm{C}$ for 2 days.

\subsection{Host-wound-parasite relation}

The methods followed for this experiment were the same as described under section 2.2 except that one set of strips was not debarked and was inoculated with actively growing Hypoxylon mycelial plugs. The other set of debarked strips was inoculated with actively growing Hypoxylon mycelial plugs. The third set of strips was debarked and inoculated with just sterile agar plugs. This was done so that conditions with wounded bark plus fungus, wounded bark and no fungus, and unwounded bark plus fungus were acquired.

\subsection{Production of exudates by Alternaria sp.}

Aspen bolts were cut into strips and debarked. Alternaria mycelial plugs were placed over the debarked areas. The pans were incubated at $25^{\circ} \mathrm{C}$. 


\subsection{Determination of the dry weights of the exudates}

The dry weights of the crude exudates were determined by taking $1 \mathrm{~m}$ of the exudates in pre-weighted test-rubes and evaporated to dryness in a Vortex Evaporator (Searle) at $50^{\circ} \mathrm{C}$ until constant weight was achieved.

\section{Results}

\subsection{Isolation of H. mammatum}

It was not possible to isolate Hypoxylttm mammatum from diseased material collected during fall and winter seasons. However, the fungus was easily isolated during the months of March and April. Best isolations were achieved during the flushing of aspen leaves.

\subsection{Effect of the exudates on the germination of Hypoxylon ascospores}

Having isolated the pathogen, experiments could be initiated to investigate the role of phytoalexins during the process of infection. Therefore, freshly wounded aspen bolts were inoculated with mycelial plugs from different strains of $H$.mammatum. After four days of inoculations, honey coloured to dark brown exudates were collected and tested against the germination of Hypoxylon ascospores to determine whether these exudates had any inhibitory activity against ascospore germination (Table 1).

Table 1

Inhibition of Hypoxylon mammatum ascospore germination by the exudates produced by different strains on inoculated aspen bolts

\begin{tabular}{|l|c|c|c|}
\hline \multirow{2}{*}{ Strains } & \multicolumn{2}{|c|}{ Average germination percentage } & Inhibition \% \\
\cline { 2 - 4 } & Treatment & Control & \\
\hline MWL I & 10.0 & 50.0 & 80.0 \\
MWL II & 2.4 & 49.2 & 95.12 \\
MWL III & 6.0 & 50.8 & 88.19 \\
MWL IV & 13.2 & 51.2 & 74.22 \\
MWL V & 3.4 & 49.8 & 93.17 \\
Q & 13.0 & 50.0 & 74.0 \\
\hline
\end{tabular}

The data are the average of five readings. Each reading was the result of counting 100 spores. The inhibitory power varied from 95.12 per cent to 74.0 per cent depending on the fungal strain.

\subsection{Action of the exudates against Alternaria sp. spore germination}

To determine whether these exudates could fulfill MüLLER's postulate regarding the nonspecific toxic nature of the aspen phytoalexins towards fungi, these exudates were tested against the Alternaria sp. which was isolated from leaves of hybrid poplars (Table 2).

The data are the average of six readings. Each reading was the result of counting 100 spores. It was observed that the germinating spores produced "Halos" around the emerging germ tubes. 
Table 2

Inhibition of the Alternaria sp. spore germination by the exudates from inoculated aspen bolts

\begin{tabular}{|c|c|c|c|}
\hline \multirow{2}{*}{ Suains } & \multicolumn{2}{|c|}{ Average germination percemtage } & \multirow{2}{*}{ lahibition $\%$} \\
\hline & Treatment & Comtrol & \\
\hline MWL.I & 6.8 & 83.0 & 91.8 \\
\hline MWL.III & 7.5 & 83.4 & 91.01 \\
\hline MWI.V & 25.1 & 83.8 & 70.05 \\
\hline
\end{tabular}

\subsection{The effect of exudates on myeclial growth of Aiternaria sp. and Hypoxylon}

The exudates were tested against the mycelial growth of Alternaria sp. on seeded plates. After 48 hours inhibition zones appeared around the filter paper discs impregnated to saturation with the water extract. The colony density of Altemaria sp. decreased with four days of incubation (Table 3). Impregnated sterile filter paper discs were placed near the mycelial fangs of H.mammatum to see whether these exudates could inhibit the mycelial growth of Hypoxylon. The exudates were not capable of inhibiting mycelial growth of Hypoxylon, indicating the differential action of the exudates against fungi. Hypoxylon continued its normal growth over, as well as under, the sterile filter paper discs.

Table 3

Inhibition of nycelial growth of Altermaria sp.

\begin{tabular}{|c|c|}
\hline $\begin{array}{l}\text { Inhibition zones } \\
\text { in cons }\end{array}$ & $\begin{array}{c}\text { Avernge inhibitions } \\
\text { zolse in cums }\end{array}$ \\
\hline 3.5 & \multirow{4}{*}{2.9} \\
\hline 3.0 & \\
\hline 2.7 & \\
\hline 2.5 & \\
\hline
\end{tabular}

Table 4

Dry weight of the exudates

\begin{tabular}{|l|c|}
\hline Strains & $\begin{array}{c}\text { Dry weight of } \\
\text { cxudates }\end{array}$ \\
\hline MWL.I & $0.0012 \mathrm{~g}$ \\
MWL.II & $0.0020 \mathrm{~g}$ \\
MWL.II & $0.0038 \mathrm{~g}$ \\
MWLIV & $0.0038 \mathrm{~g}$ \\
MWL.V & $0.0021 \mathrm{~g}$ \\
Q & $0.0016 \mathrm{~g}$ \\
\hline
\end{tabular}

\subsection{Dry weight of the exudates}

From the foregoing results it appears as if there is a difference in the inhibitory power of exudates according to the fungil stains (Table 1). However, this difference could be a quantitative or a qualitative one. 'Fo test the first assumption, the dry weight of the exudates was determined (Table 4).

Based on the dry weights, there is a difference in the ability of different fungal strains to trigger the exudate formation by the host. Therefore, based on the dry weights and also on the inhibitory capacity, the strains selected for further work were MWLI, MWL III and MWLV.

\subsection{Production of exudates by the fungus}

Experiments were carried out to see whether the exudates were produced either by fungus alone, by the host, or whether they were produced duc to the effect of wounding without any fungal implication. Only wounded wood inoculated with the fungus produced exudates, whereas wounded wood inoculated with sterile agar plugs did not produce exudates. Similarly, non-wounded wood inoculated with the fungus failed to produce any exudates. 
There is, therefore, an interaction between the host and the parasite, in the presence of a wound, for the production of exudates.

\subsection{The possibility of Hypoxylon ascospores producing exudates}

Tests were done to determine if the ascospores of Hypexylon could induce the host to produce exudates during the process of germination. For these tests, aspen strips were prepared as described in section 3.2. Instead of mycelial plugs, the debarked areas were inoculated with a spore suspension at a concentration of 100000 spores $/ \mathrm{ml}$.

Afrer four days of incubation no exudates were produced.

\subsection{To test whether an increase in mycelial inoculum would increase the exudate production}

Since the production of exudates, following the method using circular mycelial plugs on debarked rings was small, it was decided to see if an increase in mycelial inoculum would induce the host to produce larger amounts of exudates. For this purpose aspen strips were debarked lengthwise to the length of the strip instead of debarked rings as mentioned in section 3.2. Aspen strips were inoculated with agar strips containing actively growing fungus.

The host failed to produce any exudates after the required time of incubation. Interestingly, the fungus colonized the whole surface area of the host after about 72 hours.

\subsection{Test to show that the exudates are produced by the host and not by the fungus}

The problem of the biological origin of toxic compounds that are formed in host-parasite interactions has, in many cases, been in doubt. Clearly, the above compounds designated as phytoalexins are of host origin and they are not formed as specific responses to specific fungi (CrUICKSHANK 1963). To confirm this conclusion, aspen strips were inoculated with Altemaria sp. mycelial plugs and incubated at $28^{\circ} \mathrm{C}$. At the end of the incubation period, the host produced a considerable amount of exudates. Thus, aspen could be induced to produce exudates not only by H. mammatum but also by another fungus which is a leaf parasite on poplars but not a trunk parasite on trembling aspen. This indicated that the exudates were not produced by the fungus but by the host itself.

\subsection{Can Populus deltoides produce exudates when inoculated with Hypoxylon?}

Populus deltoides is resistant to H.mammatum (Berber and Rogers 1964). This resistance could be due to the ability of the host to produce phy toalexins or due to some other factors. If all the answers pointed towards the ability of phytoalexin production then was this ability a quantitative or qualitative one?

To elucidate these topics, experiments were carried out to find if $P$. deltoides could produce exudates and, if so, to compare them with those produced by $P$. tremuloides for their inhibitory power against the germination of spores. $P$. deltoides strips were inoculated with Hypoxylon and after the required incubation period exudates were produced in large quantities, as compared to those produced by P. tremuloides. Spore germination tests with Alternaria sp. showed that the exudates produced from $P$. deltoides had a low inhibitory power as compared to those produced by $P$. tremuloides (Table 5 ).

Although $P$. deltoides produced larger amounts of exudates, these did not have the same inhibitory power as those produced by P. tremuloides. 


\section{Tables}

Inhibition of Alternaria sp. spore germination by exudates from P. deltoides and P. tremuloides

\begin{tabular}{|c|c|c|}
\hline Lxudates & Avcrage germination percentage & Inhibicion percentage \\
\hline P. deltoides & 86.83 & 8.26 \\
P.trchuloides & 3.70 & 96.1 \\
Control & 94.65 & 0 \\
\hline
\end{tabular}

\section{Discussion}

During the present study, the isolation of H.mammatum was not successful during Fall or Winter months. Possible reasons for the success in isolating the fungus in the Spring, could be that fungal activity is probably greater in Spring because of the low inhibicory power of the bark (Hubiss 1964). Also, there could be a close relationship between the increase in the sap flow and availability of particular nutrients during the growing season influencing fungal activity.

Freshly wounded aspen stems could be indued to produce phytoalexins by a fungus (Alternaria sp.) other than H. mammatm. 'This indicates that these compounds are of host origin and are not formed as a specific response to specific fungi which is similar to the results obtained by CRUICKSHANK (1963).

Phytoalexins were only produced when smaller areas of the stem were wounded. When larger areas were wounded, no phytoalexins were formed. Müller (1958) and Uehara (1959) have shown a correlation between inoculum concentration and fungitoxic activity of the substance by the host. Similar studies showed a direct relationship between concentration of inoculum and concentration of pisatin formed (CRUICKSHANK and PERRIN 1963). The failure of the host to produce phy toalexin due to the increase of inoculum on wounded bark strips indicates that the increase in inoculum will not induce the host to produce larger amounts of exudates. Therefore, this falure could be atributed to the host being overcome by the parasite before it could react, or due to the rapid death of the underlying tissues caused by excessive wounding of the host.

When the aspen phytoalexins were tested against the germination of Hypoxylon ascospores, they were inhibitory in nature and the inhibiery capacity depended on the strains (I'LORES 1977). In addition, they showed a high inhibition against the gemination of Alternaria sp. spores, indicating that these phytoalexins are not specific in nature against particular fungi. "This agrees with the phytoalexin theory by Münler and BORGER (1940).

When these phytoalexins were tested against mycelial growth of H.mammatum, they had no inhibitory effect. However, they were inhibitory against mycelial growth of Alternaria $\mathrm{sp}$. The conflicting reports regarding infection of aspens by ascospores of $H$. mammatum could be due to phytoalexins which are inhibitory against ascospore germination. BERBEE and ROGERS (1964) and SHFA (1963) found that artificial inoculations were successful only when mycelial plugs were used. Therefore, aspen phytolexin probably plays an important role during the time of infection due wo its inhibitory power against ascospore germination and its non-toxic effect against mycelium.

A great number of plants can be induced to produce phytoalexins when inoculated with the spore suspension of pathogenic or even non-pathogenic fungi (Cruickshank 1963; Müller 1958; Ufhara 1959). However, H. mammatum ascospores did not induce aspen stem to produce any phytoalexin. The failure of the spore suspension to induce the host to produce phy toalexin could be attributed to the low germination percentage and relatively long periods of incubation (HuBses 1966) of Hypoxylon ascospores under nomal conditions. 
Only recently wounded aspen stems inoculated with Hypoxylon mycelium, produced phytoalexin, whereas wounded aspen strips inoculated with sterile agar plugs did not. Also non-wounded aspen strips inoculated with Hypoxylon failed to produce phytoalexin. These results give a clear indication for the host-parasite interaction in the presence of a wound. For the production of phytoalexin in aspen, one would have to consider three equally important factors: host, parasite, and wound.

Experiments carricd out to determine whether Populus deltoides could produce phytoalexin, indicate that the amount of phytoalexin produced by $P$. deltoides was greater than that produced by P. tremulnides. However, when tested at original concentration, against the germination of Alternaria sp. spores, phytoalexin from $P$. deltoides showed a lower inhibitory power compared to the one produced by $P$. tremuloides. This could be due to a higher amount of phytoalexin produced by $P$. deltoides but having a lower concentration as that of $P$. tremuloides. Other possible reasons for $P$. deltoides being resistant to $\mathrm{H}$. mammatum could be due to its ability to produce callus faster than P. tremuloides, to avoid infection by H.mammatum. The possibility of other chemical factors being present in $P$. deltoides should not be ruled out.

No experiments were performed to test if there is a difference in phytoalexin production between the different stem sections, or a variation with seasons or sites. Since these experiments were all performed in vitro on stem secrions it would be interesting to investigate the possibility of phytoalexin production in nature.

\section{Acknowledgements}

The authors wish to express their apprecintion for financial assistance provided by the Canadian Fores. try Service (Canadian Department of the Environment), the National Research Council and the Ontario Ministry of Colleges and Universities for the Ontario Graduate Scholarship.

\section{Summary}

Freshly wounded stems of Populus tremuloides produced phytoalexin when inoculated with mycelial plugs of Hypoxylon mammatum and Alternaria sp. which was inhibitory against spore germination of H. mammatum and Alternaria sp. However, H. mammatum ascospores failed to elicit the host to produce phytoalexin. The phytoalexin inhibited the growth of Alternaria sp. but failed to inhibit mycelial growth of H.mammatum. Increase in size of wound and inoculun did not produce any phytoalexin. The production of phytoalexin was the result of host-parasite interaction.

\section{Résumé}

La production de phytoalexin par Populus tremuloides Michx. comme résultat de l'infection avec Hypoxylon mammatum (Wabl.) Mill. et Alternaria spp.

Des sections fraiches du trone du Populus tremuloides (Michx.) produisent des phytoalexins après inoculation de l'écorce blessé avec nycelium du Hypoxylon mammatum (Wahl) Mill et d'Alternaria sp. Ces phytoalexins inhibent la croissance du nycélium d'Alternaria sp., la germination des conidies d'Alternaria sp., la germination des ascospores du Hypoxylon mammatum mass mais ne pas la croissance de sa mycélium.

\section{Zusammenfassung}

Die Bildung von Phytoalexin durch Populus tremuloides Michx. als Folge der Infcktion mit Hypoxylon mammatum (Wabl.) Mill. und Alternaria spp.

Frisch geschnittene Stammabschnitte von Populus tremuloides (Michx.) erzeugen Phytoalexine nach Beimpfung der verwundeten Rinde mit Myzel von Hypoxylon mammatum und Alternaria sp. Die Hemmwirkung dieser Phytoalexine ersireckt sich auf die Ascosporenkeimung von H. mammatum, die Konidienkeimung von Altemaria sp., das Myzelwachstum von Alternaria sp., nicht aber auf das Myzel wachstum von $H$. mammatum. 
BFrbe:, J. G.; Rogers, J. D., 1964: Life cycle and host range of Hypoxylon pruinatum and its pathogenesis on poplars. Phytopath. 54, 257-261.

Cruickshank, I. A. M., 1963: Phytoalexins. Ann. Rev. Phylopathology 1, 351-374.

Cruickshank, I. A. M.; Plarrin, D. R., 1963: Studics on Phytoalexins VI, The effect of some factors on its formation in Pistm satioum and the significance of pisatin in disease resistance. Aust. J. Biol. Sci. $16,111-128$.

Fi.ORI:S, C., 1977: The role of phytoalexins in the host parasite relationship of Aspen (Populus tremu-

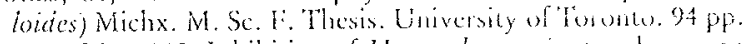

Hubses, M., 1962: Inhibition of Hypoxylon primatum by pyrocatechol isolated from bark of aspen. Science 136, 156.

-.- 1962a: Two glycosides from aspen fungistatic against Hypoxylon prumatum (Klot.) Cke. Can. Dept. Forestry, Forest Entomol. Pathol. Branch. Bi-monthly Progr. Rept. 18 (6), 2-3.

- 1964: New facts on host-parasite relationships on Hypoxylon canker of aspen. Can. J. Bot. 42, $1489-1494$.

- 1966: Inhibition of Hypoxylon pruinatum by aspen bark meal and the nature of active extractives. Can. J. Bot. 44, 365-386.

INGHAM, J. A., 1973: Disense resistance in higher plants. The concept of pre-infectional and postinfectional resistance. Phytopath. Z. 78, 314-335.

MüLLFR, K. O., 1958: Studies of phytoalexins I. The formation and the immunological significance of phytoalexins produced by Phaseolus vulgaris in response to infection with Sclerotinia fructicola and Phytophthora infestans. Aust. J. Biol. Sci. 11, 275-300.

MüLIER, K. O.; BORGER, H., 1940: Experimentelle Untersuchungen über die Phytophthora-Resistenz der Kartoffel. Arb. Biol. Reichsanstalt Land-u. Forstwiss. 23, 189-231.

SHFA, K. R., 1963: Induction of Hypox: lon cankers in aspen by artificial inoculation. Forest Sci. 9, 227

UeHARA, K., 1959: On phytoalexin production of the soyabean in reaction to Fusarium sp. the causal fungus of pod blight. II. On the effect of conditions of the spore suspension of the causal fungus upon phytoalexin production. Ann. Plyytopathol. Soc. Japan 24, 224-228.

Authors' address: G. Fiones and Prof. Dr. M. Hubiss, University of Toronto, Faculty of Forestry and Landscape Ardifecture, 203 College Street, Toronto M5S IA 1, Canada

\title{
The influence of chemical factors on the selectivity of Pinus resinosa stumps for Fomes annosus
}

\author{
I. In vitro studies on chemical changes in Pinus resinosa \\ as a response to wounding
}

By J.-Y. C. Lin and M. HubBes

Receipt of Ms. 10.8.1978

\begin{abstract}
Fresh pine stump surfaces act selectively for primary invaders such as Fomes annosus that competes successfully against other microorganisns. However, a series of chemical reactions on the stump surface due to acriation and the hosts response to wounding may be implicated in the selectivity of the host for certain microorganisms. The theory of stump selectivity of coniferous trees for $F$ annosus as well as the theory of wound reaction and protection wood are discussed. The sequence of events after wounding is complicated and the present investigation concentrates on the processes associated with the host response to wounding.
\end{abstract}

U.S. Copyright Clearance Center Code Statement : 0300-1237/79/0905/0288 \$02.50/0

Eur. J. For. Path. 9 (1979) 288-298

(C) 1979 Verlag Paul Parcy, Hamburg und Berlin

ISSN 0300-1237/ ASTM-Coden : IJIPA? 